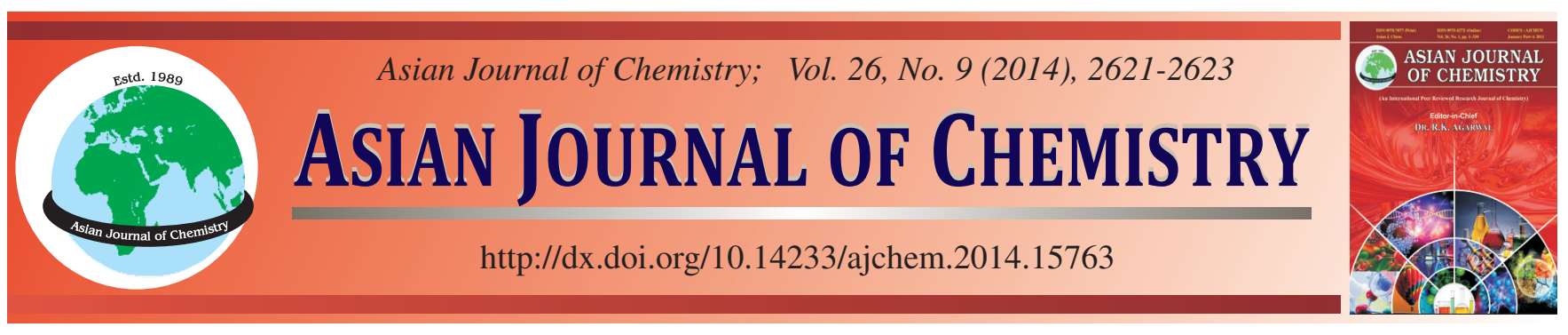

\title{
A New Phenolic Compound from the Stems of Flue-Cured Tobacco and Its Anti-Tobacco Mosaic Virus Activity
}

Yong Kuan Chen, Zhinua Liu, Xia Zhang, Yi Han, Su Zhongbi, Guangyu Yu Yang and Ming Ming Miao*

Key Laboratory of Tobacco Chemistry of Yunnan Province, Yunnan Academy of Tobacco Science, Kunming 650106, P.R. China

*Corresponding author: E-mail: mmmiao@cyats.com

Received: 14 May 2013;

Accepted: 17 August 2013;

Published online: 28 April 2014;

AJC-15082

\begin{abstract}
A new phenolic compound, $(E)$-7-(3,7-dimethylocta-2,6-dienyl)-4-methoxybenzofuran-2(3H)-one (1), was isolated from the stems of flue-cured tobacco (a variety of Nicotiana tabacum L). Its structure was elucidated by spectroscopic methods, including extensive $1 \mathrm{D}$ and 2D NMR techniques. Compound $\mathbf{1}$ was tested for its anti-tobacco mosaic virus (anti-TMV) activity and it shows potential anti-tobacco mosaic virus activity with inhibition rates of $12.5 \%$.

Keywords: Phenolic compound, Flue-cured tobacco, Anti-tobacco mosaic virus activity.
\end{abstract}

\section{INTRODUCTION}

Nicotiana tabacum L. is a perennial herbaceous plant. It is found only in cultivation, where it is the most commonly grown of all plants in the nicotiana genus and its leaves are commercially grown in many countries to be processed into tobacco $^{1,2}$. In addition to being used in cigarette industry, $N$. tabacum is also used as insecticide, anesthetic, diaphoretic, sedative and emetic agents in Chinese folklore medicine because of it containing many useful chemical compounds ${ }^{1,3-5}$. In previous work, a number of bioactive compounds, such as terpenoids $^{6-8}$, alkaloids ${ }^{9,10}$, lignans $^{11,12}$, flavonoid ${ }^{13}$, phenyl-propanoids ${ }^{14}$ and the homologous, were isolated from this plant. The stems and roots of $N$. tabacum are big amount of byproduct in tobacco planting and are normally used as organic fertilizer. The multipurpose utilization of the stems and roots of $N$. tabacum is an interesting topical and receives more and

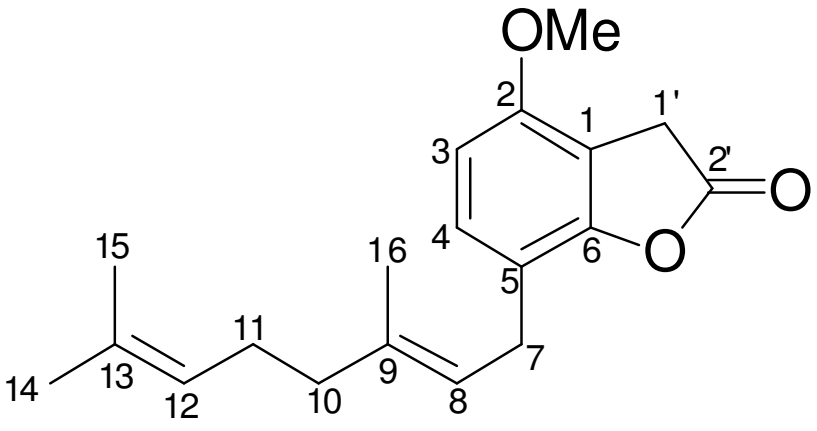

Fig. 1. Structure of new phenolic compound more attentions ${ }^{15-17}$. With the aims of search for bioactive metabolites from this plant, the investigation on the chemical constituents of the steams of flue-cured tobacco (a variety of Nicotiana tabacum L) was carried out. As a result, a new phenolic compound (1) (Fig. 1) was isolated. In addition, the anti-tobacco mosaic virus (anti-TMV) activity of $\mathbf{1}$ was evaluated. This article deals with the isolation, structural elucidation and biological activities of this new compound.

\section{EXPERIMENTAL}

UV spectra were obtained using a Shimadzu UV-2401A spectrophotometer. IR spectra were obtained in $\mathrm{KBr}$ disc on a Bio-Rad Wininfmred spectrophotometer. ESI-MS were measured on a VG Auto Spec-3000 MS spectrometer. ${ }^{1} \mathrm{H},{ }^{13} \mathrm{C}$ and 2D NMR spectra were recorded on Bruker DRX-500 instrument with TMS as internal standard. Column chromatography was performed on silica gel (200-300 mesh), or on silica gel H (10-40 $\mu \mathrm{m})$, Qingdao Marine Chemical Inc., China). Preparative HPLC was used an Agilent 1100 HPLC equipped with ZORBAX-C18 (21.2 mm × $250 \mathrm{~mm}, 7.0 \mu \mathrm{m})$ column and DAD detector.

The stems of flue-cured tobacco were collected in Yuxi Prefecture, Yunnan Province, People's Republic of China, in September 2011. The identification of the plant material was verified by Prof. Chen Y.J. (Yunnan University of Nationalities).

Extraction and isolation: The air-dried and powdered stems of tobacco stems $(2.2 \mathrm{~kg})$ were extracted 4 times with $90 \%$ methanol $(4 \times 5 \mathrm{~L})$ at room temperature and filtered to 
yield a filtrate. The crude extract $(85.2 \mathrm{~g})$ was applied to silica gel (200 - 300 mesh) column chromatography, eluting with a chloroform-acetone system $(20: 1,9: 1,8: 2,7: 3,6: 4,5: 5)$, to give six fractions A-F. The further purification of fraction A (20:1, $22.4 \mathrm{~g})$ by silica gel column chromatography, eluted with petroleum ether-acetone $(9: 1,8: 2,7: 3,6: 4,5: 5)$, yielded mixtures A1-A5. Fraction A2 $(8: 2,1.65 \mathrm{~g})$ was subjected to preparative $\mathrm{HPLC}\left(75 \% \mathrm{MeOH}-\mathrm{H}_{2} \mathrm{O}\right.$, flow rate $\left.12 \mathrm{~mL} / \mathrm{min}\right)$ to yield compound $\mathbf{1}(14.3 \mathrm{mg})$.

(E)-7-(3,7-dimethylocta-2,6-dienyl)-4-methoxybenzofuran-2(3H)-one: Obtained as a white amorphous powder; UV (MeOH), $\lambda_{\max }(\log \varepsilon) 278$ (3.98), $210(4.30) \mathrm{nm}$; IR (KBr, $\left.\lambda_{\max }, \mathrm{cm}^{-1}\right) 3028,2965,2918,1768,1602,1536,1449,1150$, 1105,$894 ;{ }^{1} \mathrm{H}$ NMR and ${ }^{13} \mathrm{C} \mathrm{NMR}$ data $\left(\mathrm{C}_{5} \mathrm{D}_{5} \mathrm{~N}, 500 \mathrm{MHz}\right.$ and $125 \mathrm{MHz}$, respectively), (Table-1); ESIMS (positive ion mode), $\mathrm{m} / \mathrm{z} 323[\mathrm{M}+\mathrm{Na}]^{+}$; HRESIMS (positive ion mode), $\mathrm{m} / \mathrm{z}$ $323.1628[\mathrm{M}+\mathrm{Na}]^{+}$(calcd. 323.1623 for $\mathrm{C}_{19} \mathrm{H}_{24} \mathrm{O}_{3} \mathrm{Na}$ ).

\section{RESULTS AND DISCUSSION}

Compound 1 was obtained as white amorphous powder. Its molecular formula was determined as $\mathrm{C}_{19} \mathrm{H}_{24} \mathrm{O}_{3} \mathrm{Na}$ by

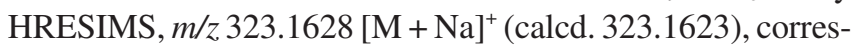
ponding to 8 degrees of unsaturation. Its ${ }^{1} \mathrm{H}$ and ${ }^{13} \mathrm{C}$ NMR spectral data (Table-1) showed signals to 24 hydrogens and 19 carbons, respectively, corresponding to one aromatic ring $\left(\delta_{\mathrm{C}} 115.6 \mathrm{~s}, 155.4 \mathrm{~s}, 112.7 \mathrm{~d}, 129.0 \mathrm{~d}, 128.6 \mathrm{~s}, 135.8 \mathrm{~s}\right)$ with two aromatic protons (6.82 (d) $J=8.8,7.26$ (d) $J=8.8$ ), one geranyl moiety ${ }^{18}\left(\delta_{\mathrm{C}} 28.2 \mathrm{t}, 121.6 \mathrm{~d}, 138.2 \mathrm{~s}, 33.6 \mathrm{t}, 26.0 \mathrm{t}\right.$, $124.6 \mathrm{~d}, 131.2 \mathrm{~s}, 25.2 \mathrm{q}, 18.2 \mathrm{q}, 16.8 \mathrm{q} ; \delta_{\mathrm{H}} 3.22$ (d) $J=7.2$, $5.26(\mathrm{t}) J=7.2,2.22 \mathrm{~m}, 2.18 \mathrm{~m}, 5.06 \mathrm{~m}, 1.62 \mathrm{~s}, 1.50 \mathrm{~s}, 1.68 \mathrm{~s})$, a furan-2(3H)-one ${ }^{18}(39.2 \mathrm{t}, 175.0 \mathrm{~s} ; 3.58 \mathrm{~s})$ and a methoxy group $\left(\delta_{\mathrm{C}} 56.2 \mathrm{q} ; \delta_{\mathrm{H}} 3.81 \mathrm{~s}\right)$. Strong absorption bands accounting for carbonyl $\left(1768 \mathrm{~cm}^{-1}\right)$ and aromatic group $(1602,1536$, $1449 \mathrm{~cm}^{-1}$ ) could be observed in its IR spectrum. The UV spectrum of 1 showed absorption maxima at 278 and $210 \mathrm{~nm}$ also confirmed the existence of the aromatic function. The HMBC correlations (Fig. 2$)$ of H-7 $\left(\delta_{\mathrm{H}} 3.22\right)$ with C-4 $\left(\delta_{\mathrm{C}}\right.$ $129.0), \mathrm{C}-5\left(\delta_{\mathrm{C}} 128.6\right)$ and $\mathrm{C}-6\left(\delta_{\mathrm{C}} 135.8\right)$, of H-4 $\left(\delta_{\mathrm{H}} 7.26\right)$ with $\mathrm{C}-7\left(\delta_{\mathrm{C}} 28.2\right)$ suggested the geranyl moiety was attached to $\mathrm{C}-1$. The long-range correlation of the methoxy proton signal $\left(\delta_{\mathrm{H}} 3.81\right)$ with $\mathrm{C}-2\left(\delta_{\mathrm{C}} 155.4\right)$ clearly indicated that the methoxy group located at $\mathrm{C}-2$. The $\mathrm{HMBC}$ correlations of $\mathrm{H}-1^{\prime}\left(\delta_{\mathrm{H}} 3.58\right)$

\begin{tabular}{|c|c|c|c|c|c|}
\hline \multicolumn{6}{|c|}{$\begin{array}{c}\text { TABLE-1 } \\
{ }^{1} \mathrm{H} \text { NMR AND }{ }^{13} \mathrm{C} \text { NMR DATA OF COMPOUND } 1 \\
\left(\mathrm{C}_{5} \mathrm{D}_{5} \mathrm{~N}, \delta \text {, ppm, } J(\mathrm{~Hz})\right.\end{array}$} \\
\hline No. & $\begin{array}{c}\delta_{\mathrm{C}} \\
\text { (mult.) }\end{array}$ & $\delta_{\mathrm{H}}($ mult, $J, \mathrm{~Hz})$ & No. & $\begin{array}{c}\delta_{\mathrm{C}} \\
\text { (mult.) }\end{array}$ & $\begin{array}{c}\delta_{\mathrm{H}}(\mathrm{mult}, J, \\
\mathrm{Hz})\end{array}$ \\
\hline 1 & $115.6 \mathrm{~s}$ & & 11 & $26.0 \mathrm{t}$ & $2.18, \mathrm{~m}$ \\
\hline 2 & $155.4 \mathrm{~s}$ & & 12 & $124.6 \mathrm{~d}$ & $5.06, \mathrm{~m}$ \\
\hline 3 & $112.7 \mathrm{~d}$ & $6.82, \mathrm{~d}, J=8.8$ & 13 & $131.2 \mathrm{~s}$ & \\
\hline 4 & $129.0 \mathrm{~d}$ & $7.26, \mathrm{~d}, J=8.8$ & 14 & $25.2 \mathrm{q}$ & $1.62, \mathrm{~s}$ \\
\hline 5 & $128.6 \mathrm{~s}$ & & 15 & $18.2 \mathrm{q}$ & $1.50, \mathrm{~s}$ \\
\hline 6 & $135.8 \mathrm{~s}$ & & 16 & $16.8 \mathrm{q}$ & $1.68, \mathrm{~s}$ \\
\hline 7 & $28.2 \mathrm{t}$ & $3.22, \mathrm{~d}, J=7.2$ & $1^{\prime}$ & $39.2 \mathrm{t}$ & $3.58, \mathrm{~s}$ \\
\hline 8 & $121.6 \mathrm{~d}$ & $5.26, \mathrm{t}, J=7.2$ & $2^{\prime}$ & $175.0 \mathrm{~s}$ & 10.8 brs \\
\hline 9 & $138.2 \mathrm{~s}$ & & $\begin{array}{l}2- \\
\mathrm{OMe}\end{array}$ & $56.2 \mathrm{q}$ & $3.81 \mathrm{~s}$ \\
\hline 10 & $33.6 \mathrm{t}$ & $2.22, \mathrm{~m}$ & & & \\
\hline
\end{tabular}

with C-1 $\left(\delta_{\mathrm{C}} 115.6\right), \mathrm{C}-2\left(\delta_{\mathrm{C}} 155.4\right), \mathrm{C}-6\left(\delta_{\mathrm{C}} 135.8\right)$ and the carbonyl carbon $\left(\delta_{\mathrm{C}} 175.0\right)$ indicated that the furan-2(3H)-one should be fused at $\mathrm{C}-1$ and $\mathrm{C}-6$. The protons signals $\left(\delta_{\mathrm{H}} 6.82\right.$ (d) $J=8.8,7.26$ (d) $J=8.8$ ) also supported the substituents position on the aromatic ring. Thus, the structure of $\mathbf{1}$ was established as (E)-7-(3,7-dimethylocta-2,6-dienyl)-4-methoxybenzofuran-2(3H)-one.

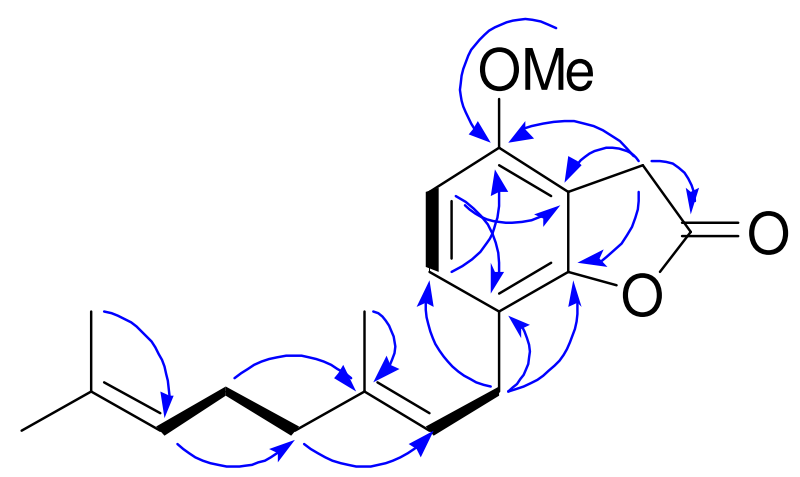

\section{$\mathrm{HMBC}(\frown){ }^{1} \mathrm{H}-{ }^{1} \mathrm{H} \cos Y(-)$}

Fig. 2. Key HMBC and ${ }^{1} \mathrm{H}-{ }^{1} \mathrm{H}$ COSY correlations of $\mathbf{1}$

Since certain of the phenolic compounds exhibit potential anti-TMV activity ${ }^{19-21}$, compounds 1 was tested for it anti-tobacco mosaic virus activity. The anti-TMV activities were tested using the half-leaf method ${ }^{21}$. Ningnanmycin ( $2 \%$ water solution), a commercial product for plant disease in China, was used as a positive control. The results showed that compound $\mathbf{1}$ exhibited inhibition rates of $12.5 \%$.

\section{ACKNOWLEDGEMENTS}

This project was supported financially by the Basic Research Foundation of Yunnan Tobacco Industry Co. Ltd (2012JC01), the National Natural Science Foundation of China (No. 31360081), the Excellent Scientific and Technological Team of Yunnan High School (2010CI08).

\section{REFERENCES}

1. The Editorial Committee of the Administration Bureau of Flora of China, Flora of China, Vol. 67, Beijing Science and Technology Press, Beijing (2005).

2. T.W. Hu and Z. Mao, Tob. Control, 15(suppl-1), i37 (2006).

3. A. Rodgman and T.A. Perfetti, The Chemical Components of Tobacco and Tobacco Smoke, CRC Press, Taylor and Francis Group, Boca Raton, Florida (2008).

4. A.P. Cavender and M. Alban, J. Ethnobiol. Ethnomed., 5, 3 (2009).

5. A. Inta, P. Shengji, H. Balslev, P. Wangpakapattanawong and C. Trisonthi, J. Ethnopharmacol., 116, 508 (2008).

6. X. Feng, J.-S. Wang, J. Luo and L.-Y. Kong, J. Asian Nat. Prod. Res., 12, 252 (2010).

7. Y. Shinozaki, T. Tobita, M. Mizutani and T. Matsuzaki, Biosci. Biotechnol. Biochem., 60, 903 (1996).

8. T. Pettersson, A.M. Eklund and I. Wahlberg, J. Agric. Food Chem., 41, 2097 (1993).

9. X.C. Wei, S.C. Sumithran, A.G. Deaciuc, H.R. Burton, L.P. Bush, L.P. Dwoskin and P.A. Crooks, Life Sci., 78, 495 (2005).

10. T. Braumann, G. Nicolaus, W. Hahn and H. Elmenhorst, Phytochemistry, 29, 3693 (1990). 
11. Y.K. Chen, X.S. Li, G.Y. Yang, Z.Y. Chen, Q.F. Hu and M.M. Miao, J. Asian Nat. Prod. Res., 14, 450 (2012).

12. Q.-F. Hu, G. Yang, X. Li, X. Yang, H. Mu, Y. Chen and X.-M. Gao, Heterocycles, 85, 147 (2012).

13. Z.Y. Chen, J.L. Tan, G.Y. Yang, M.M. Miao, Z.Y. Chen and T.F. Li, Phytochem. Lett., 5, 233 (2012).

14. Y. Chen, T. Li, Z.-Y. Chen, G. Yang, M. Miao and J. Tan, Heterocycles, 83, 2381 (2011)

15. W. Li, L.B. Zhang, J.H. Peng, N. Li and X.Y. Zhu, Ind. Crops Prod., 27, 341 (2008)

16. Q. Hu, M. Miao, W. Zhao, T. Zhang, L. Wan, G. Yang, Y. Chen and D. Mou, Heterocycles, 85, 2485 (2012).
17. W.H. Zhong, C.J. Zhu, M. Shu, K.D. Sun, L. Zhao, C. Wang, Z.J. Ye and J.M. Chen, Bioresour. Technol., 101, 6935 (2010).

18. T. Noshita, H. Kiyota, Y. Kidachi, K. Ryoyama, S. Funayama, K. Hanada and T. Murayama, Biosci. Biotechnol. Biochem., 73, 726 (2009).

19. J.X. Chen, H.Q. Leng, Y.X. Duan, W. Zhao, G.Y. Yang, Y.D. Guo, Y.K. Chen and Q.F. Hu, Phytochem. Lett., 6, 144 (2013).

20. Q.F. Hu, B. Zhou, J.M. Huang, X.M. Gao, L.D. Shu, G.Y. Yang and C.T. Che, J. Nat. Prod., 76, 292 (2013).

21. Q.F. Hu, B. Zhou, X.M. Gao, L.Y. Yang, L.D. Shu, Y.Q. Shen, G.P. Li, C.T. Che and G.Y. Yang, J. Nat. Prod., 75, 1909 (2012). 